\title{
PUBLIC HEALTH HAZARD OF HEAVY METALS IN SOME CANNED DAIRY PRODUCTS
}

\author{
A. S. Alad and A. H. Fayed \\ Animal health rescarch insillutc (Alexandria)
}

\begin{abstract}
A Lotal of 60 random samples 120 each of milk. based infant fornula. milk pouder. and condensed in(lk) were randomly collected from different localities in Alexandria Covernorate. The collected samples were analyzed for the levels of lead, cadmium. copper and zinc by using Atomic absorplton spectropholomeler. Results revealed that the mean lead levels in the examined muk- based infant formula: milk powder and con. densed nilk were $0.44 \pm 0.093 .0 .23 \pm 0.038$ and $0.12 \pm 0.013$ ppn. respecilively. The mean cadmium levets th the examined samples were $0.031 \pm 0.005 .0 .11 \pm 0.027$, and $0.032 \pm 0.005 \mathrm{ppm}$, respectlvely. The mean copper levels in the examined samples were $0.86 \pm 0.094 .0 .21 \pm 0.024$, and $0.053 \pm 0.003 \mathrm{ppm}$, respectively. While, the mean zinc levels in the examlned samples were $0.50 \pm 0.019,0.49 \pm 0.014$ and $0.10 \pm$ $0.007 \mathrm{ppm}$ respectively. This study pointed to protect human and anlinal from exces. slue inlake of heawy metals.
\end{abstract}

\section{INTRODUCTION}

Environmental pollutlon whth heavy metals leads 10 growing Interest in metal contimination of mllk and milk products which represent an Important part li human diet especially for chll. dren. Heavy metals represent one of the most important groups of pollutants in lood supply (Protasowickl. 1992). The amount of different heavy melals has been increased with the devel. opment of human civtlization. an additional concern aboul their concentration in domestc and Industrlal waste products. Also. heavy metals may contaminate food by a leaching process belween the food and It's contalners (Kagsted and Hubbert 1986).

The toxlc elements which are considered of major incerest in dalry producis include lead and cadmium. These metals of recognlzed toxiclty and their presence in food at significant concentra. tlon is a potenllal health hazard (Bawn and Shanoon, 1987).

Lead is one of the most important pollutants in our environment which accumulates in the body due lo ils low rale of ellminacion: its blological half lire in bone is about 27 years (Shlbamo- 
to and Bjelanes 1993). Chronle lead polsoning is charactertzed by neurologlca) effects Inciuding encephalopathy and peripheral neuropathy. It is also affects renal tissues producing acute and chrontc nephropathy as well as hypertension and fiver dyslunction. A strct correlacion has found between chronic exposute to low lead doses and neuropsychological impaiment in hist chlldhood was ofen reported (Guldi et al., 1956).

Cadmilum and its salts are ivdely employed in numerous industrial processing. It is a component of many commerclal products and found In nature in close associatlon with lead and Zinc (klaaseng, I 985). Cadmium is known to induce chronlc renal disease (Madden and Flowcr, 2000). It is also a potent pulmonary carclnogen and play significant role as a cause of hypertenston and osteomalacla (Friberg et al., 1986) also it is major contrlbutor to thyrold disease (Watanabe et al, 2000).

Zinc and copper are widely distrbuted in nature and essenllal component of several enzymes. Each essentlal metal has three levels of blologlcal actlvity, trace level requited for optmum growth and development, slorage level and loxlc level. These elements are tranlocated through the food chaln to man and animal (Pound, 1975 and Pope. 1875).

Copper is important in formation of erythrocyzes. development of bone. central nervous system and connective tissue. Both excess and deflency of copper in mammalian syslem result in serrous effects (Hootynek et al 1993). Abnormal high liver copper level lead to vartous disease including clmhosis. Medilerranean anemla. haemochromolosis, yellow atrophy of liver and Wilson's disease (Underwood, 1977).

High level of zinc in foods may be toxdc to the human body. where it causes deficiencles In other metals like copper (Kula and Lasto. 1986). Toxjclty by zlnc leads to Lremors. central nervous system depression. bloody diarrhea and Intense abdominal paln (Gasarett and Doulls. 1906).

Since heavy melals can not be destroyed or broken over long time by heat treatment or envtronmental degradation and they are persistent type of pollutants and translocated through food chaln to man and animal (Huang et al., 2003).

Therefore the alm of the present work is to Invesugate the environmental pollution with some heavy metals especlally tead. cadmlum. copper and zinc In mllk-based infant formula. milk powder and condensed milk and to suggest a protocol for prevention of this pollution in Alexandra Governorate. 


\section{MATERLALS AND METHODS}

1. Collection of eamples:-

A total of slxty representative samples of canned milk- based infanc formula: milk powder and condensed milk 20 samples of each) were randomly collecled from diffenent markels in Alexan. dria clty then transferred to laboratory for estinaton of lead. cadmlum. copper and zinc.

\section{Digestlon of samples:-}

The collected samples were prepared and digesled according to AOAC (18BO), Richerd and Rabinshaplro (1986) and kban et al., (1998).

\section{Estumation of metals:-}

Lead. cadmlum. copper and zinc were determined by using Alomic absorpllon spectrophotomeler (PERKIN. ELMER 2380). according to Agemalo et al., (1980) and kalrtgabar et al., (1982).

\section{RESULT AND DISCUSSION}

Heavy metals are considered the main contaminants causing serious bealth hazard to human and anlmal populallon through progressive In'eversible accumulation in their bodies as a result of repeated consumption of small amount of these elements (Wheatod and 1awson, 1985).

1. Lead:

Lead is considered one of the nost hazardous pollutunts to animal and human beings health status. as It is a threat to man vla food and drink or inhalauon. The presence of lead in the hu. man lood chain conlinues to be a major health problem world wide.

The obtained results revealed that the mean concentrallon of lead in examined milk. based infant formula wore $0.44 \pm 0.093 p p m$. (Table I \& Fig. 1).

Guld et al., (1996) esumaked lead content in mllk -based infant formula and found that the mean lead level was $73.139 .11 \mathrm{mg} / \mathrm{kg}$. The author hoped milk formula Industry to have a more specinc control on lead milk content (or chlldrén teeding.

Egyptian organlzation for standardization (EOS. 1883) reported that the maximum permissl. ble Ilmlt of lead in mallk- based Infant formula must be nol more than 0.1 ppm. In present study $95 \%$ or milk-based infant formula samples were exceeded the maximum permissible limit (MPL) 
of lead. (Table $2 \&$ Fig. 2). On the other hand higher resulis were reported by EL -Aglay (2005). While, lower results were oblalned by EL- Malt (2001).

The mean concentration of lead In milk powder samples were $0.23 \pm 0.038$ ppm (Tablel\& FYg. I). (EOS, 1993) reported that the maxdmum pernissible limit of lead in milk powder must be not more than $0.5 \mathrm{ppm} .25 \%$ of inllk powder samples were exceeded the maximum pertnisslble IImlt (MPL) or lead (Table2 \& Flg.2). Higher results were obtajned by Mansour (1999), while lower results were oblalned by Fayed (2001). The mean concentration of lead in examined condensed milk samples were $0.12 \pm 0.013$ ppm (Table 1 \& Fig. 1). The maximum permissible limit of lead in condensed milk samples must be not more than 0.2 ppm (IDF 1979). All condensed milk samples were complled with the allowable pernissible llmit (MPL.) of lead for human consumption (Table $2 \&$ Fig. 2). Higher results in condensed milk were obtalned by Mansour (1899).

The present study revealed a highly signibcant elevation in lead content of examined milkbased Infant formula and milk powder collected from Alexandirina. WHO (1982) Reported that the major source of lead in the environment resulting from manuracture and application of alkyl fuel additives.

\section{Cadmiun:}

Cadmium and its salts are widely employed in numerous industrlal processing. It's a component of many commerclal products and found in nature in close assoclation with lead and zinc (kDasssen, 1985). Also it is a toxic metal can cause abroad spectrum toxicological and blologlcal dysfunction (Funakoshl et al. 1995). Cadmium accumulates with the age in body Ussue and cause renal fallure (Frlberg et al, 1986). And it has a significant role in the hincidence of many other diseases such as dlabetes mellitus and hypertension (Nishlyama et al., 1986).

The mean cadmlum levels in examlned milk- based infant formula samples were $0.031 \pm$ $0.005 \mathrm{ppm}$ (Tablel \& Fig.1). The maximum permissible limit of cadinium in milk-based infant fornula was 0.05 ppm (EOS, 1883). $50 \%$ of mlk- based Infant formula were exceeded the MPL [Table 2). Higher results in milk-based Infant formula were obtained by El-Aglzy (2005). Lower resuits were oblatned by [EL-Malt 2001 ).

The mean cadmium levels In examlned mlik powder samples were $0.11 \pm 0.027 \mathrm{ppm}$ (Table $\&$ \& Fig. 1). The maximum permissible limits of cadmium In milk powder must be not more than 0.005 according w IDF (1879). Al) of milk powder samples were exceeded the MPL (Tabie2 \& Fig.2). Lower results in milk powder were reported by Fayed (2001). While. higher results 
obtalned by Maneour (1999). The mean cadmlum lcuel in examined condensed milk samples were $0.032 \pm 0.005 \mathrm{ppm}$ (Tablel \& Flg. 1). The maximuin permissible limit of cadmlum in condensed mllk samples must be nol more than 0.005 ppin (IDF, 1878). All the condensed milk samples were exceeded the maxlmum pormissible IImils (Table 2 \& Fig. 2). Lower resulis in condensed milk were obtalned by (Mansour 1999).

(Eklund and Oskarssan 1898) examlned 59 baby food samples in Sweden and found that the mean cadnilum levels ranged from $1.101023 .5 \mathrm{ppm}$.

\section{Copper:}

Copper is ari essential element for liumait and animals and act as a cofactor for several en zyme systerns Including cytochrome- oxddase and tyrosinase. Excess amount of copper in food give rlse to outbreaks of copper poisoning.

Table (1) \& Fig (1) showed that the mean concentration of copper in examined milk- based in. fant formula was $0.86 \pm 0.094$ ppni. EOS (1993) reported that the maximum permissible limil of copper In milk- based Infant formula must be not more than $5 \mathrm{ppm}$. All examined milk- based Infanc formula samples were complicd with MPL (Table 2 \& Fig. 2). Lower results in milk-based Infant formula were reported by Amer et al. (2006) whlle. higher results $(45.01 \mathrm{mg} / \mathrm{kg}$ ) were ob. Lalned by Ayoub (2002). The high level of copper In cxamined milk based infant formula may be due co the wide applicallon of copper In agrlculture and industry as fungicides and insecucides.

The oblained results revealed that the mean concentration of copper in examined milk powder samples was $0.21 \pm 0.024 \mathrm{ppm}$. Al examlned milk powder samples complled with MPL (5 ppin) EOS (1993). Higher regults In milk powder were reported by Fayed (2001) while lower results were reporled by El-Aglzy (2005).

The mean concentration of copper in exanlined condensed milk samples was $0.053 \pm 0.003$ ppm (Tablel \& Fig. I). The maximum permissible limil of copuer in condensed milk must be nol more than $0.3 \mathrm{ppm}$. (Under wood, 1977). All examined condensed milk samples were complied wlth MPL (Table 2 \& Fig. 2). Higher results in condensed mllk were obtalned by Mansour (1899).

Copper is essental element at low concentration but it is loxic at high levels. The dally inlake requlrements of copper are $30 \mathrm{\mu g} / \mathrm{kg}$ body wetght for an adult male, with larger amounts or 40 $\mu \mathrm{g} / \mathrm{kg}$ for older children and $80 \mathrm{\mu g} / \mathrm{kg}$ (or Infants (WHO 1973). Inges(lon of an excessive dose of copper may lead to sever nausea. bloody dlarrhea, hypertension and faundice: however. copper polsoning is characlenized by kaser-helscher ring which is a golden brown ring of accumulated copper on the comea of the eye. (Gosel and Bricker, 1990). 
4. Zloc:

The wde use of zinc in the home and else where in the communtly accounts for a very high level of zlnc contaminallon encountered In dust, water and atmosphere causing polsoning. In the absence of an adequate dretary supply of zinc. sertous and characterlstic doficlency symptoms artse (Reilly, 1991). Table (1) \& Fig (1) showed that the mean value of zinc in examined milkbased Infant formula samples was $0.59 \pm 0.019 \mathrm{ppm}$. The maxdmum permisstble limit of zinc In mllk- based Infant formula must be nol more than $5 \mathrm{ppm}$ (DIng et a1., 1993). All examined milk- based infant formula samples comply wth the MPL. Higher results in milk-based infant formula was obtained by Amer et al. (2006). The mean level of zlnc in examined milk powder was $0.49 \pm 0.014 \mathrm{ppm}$. The maxdinum perrnlssible llmalt of zlnc In milk powder samples was 40 ppm (Bulingkd, 1992). All mllk powder samples comply wih MPL. Higher results in mulk powder were reported by Fayed (2001). The mean level of zinc in examined condensed milk samples was $0.19 \pm 0.007$ ppm. All examined condensed milk samples comply wlth MPL which is 40 ppm. (Bulingkf et al., 1992). Higher results in condensed milk were obtained by Maasour (1999).

Excessive zInc Intate displaces copper as well as iron and interferes with copper incorporatIng tron in the prophoryn compounds; hence anemia develops (Golden and Golden 1981). Acc)dental oral zinc polsonlng has been reported in human as a result of consuming acidlc food from galvanized contalners. The symptoms of such intoxication consist of fever, vomiting, stomach cramps and dlarrhea (Schraeder and Balassa, 1967). Zlnc is abundant in tab water than surface water due to It is leaching from galvanized plpes and brass (Nariagu, 1980).

High zlnc to copper ratlo may result In interference with lipld metabollsm. The imbalarces of the dietary zinc-copper Intake have been assoclated with hypercholesterolemLa (klevag, 1975).

To minimize the health risk of heavy metals we recommended that the followng measures must be put in consideration to minlmuce the sources of heavy metals contamination in milk and milk products through encouragement of the use of unleaded benzene; application of good agrcultural and Industrlal praclices; control use of peslicides and funglcides. Milk producers and distributors should have enough Information about the danger of heavy inclals In datry products on public health and from the economlc polnt of vew. The dalry products should be produced under the modem quality assumance systcm by applicatlon of hazard analysis critical control points (HACCP) to ensure quality and safety of these products. 
Table (1): Lead, cadmium, copper and zinc levels (ppm) in examined canned dairy products.

\begin{tabular}{|r|c|c|c|c|}
\hline \multirow{2}{*}{ Product } & Lead & Cadmium & Copper & Zinc \\
\cline { 2 - 5 } & \multicolumn{4}{|c|}{ Mean \pm SEM (ppm) } \\
\hline Milk-based infant formula & $0.44 \pm 0.093$ & $0.031 \pm 0.005$ & $0.86 \pm 0.094$ & $0.59 \pm 0.019$ \\
\hline Milk Powder & $0.23 \pm 0.038$ & $0.11 \pm 0.027$ & $0.21 \pm 0.024$ & $0.49 \pm 0.014$ \\
\hline Condensed Milk & $0.12 \pm 0.013$ & $0.032 \pm 0.005$ & $0.053 \pm 0.003$ & $0.19 \pm 0.007$ \\
\hline
\end{tabular}

Table (2): Number and percent of examined canned dairy products samples above maximum permissible limits.

\begin{tabular}{|c|c|c|c|c|c|c|c|c|c|c|c|c|}
\hline \multirow{3}{*}{ Product } & \multicolumn{3}{|c|}{ Lead } & \multicolumn{3}{|c|}{ Cadmium } & \multicolumn{3}{|c|}{ Cоррет } & \multicolumn{3}{|c|}{ Zinc } \\
\hline & \multirow[t]{2}{*}{ MPL } & \multicolumn{2}{|c|}{$\begin{array}{c}\text { Samples above } \\
\text { MPL }\end{array}$} & \multirow[t]{2}{*}{ MPL } & \multicolumn{2}{|c|}{$\begin{array}{c}\text { Samples above } \\
\text { MPL }\end{array}$} & \multirow[t]{2}{*}{ MPL } & \multicolumn{2}{|c|}{$\begin{array}{c}\text { Samples above } \\
\text { MPL }\end{array}$} & \multirow[t]{2}{*}{ MPL } & \multicolumn{2}{|c|}{$\begin{array}{c}\text { Samples above } \\
\text { MPL }\end{array}$} \\
\hline & & No & $\%$ & & No & $\%$ & & No & $\%$ & & No & $\%$ \\
\hline $\begin{array}{r}\text { Milk-based infant } \\
\text { formula }\end{array}$ & 0.1 & 19 & 95 & 0.05 & 10 & 50 & 5 & 0 & 0 & 5 & 0 & 0 \\
\hline Milk Powder & 0.5 & 5 & 25 & 0.005 & 20 & 100 & 5 & 0 & 0 & 40 & 0 & 0 \\
\hline Condensed Milk & 0.2 & 0 & 0 & 0.005 & 20 & 100 & 0.3 & 0 & 0 & 40 & 0 & 0 \\
\hline
\end{tabular}


Q Mllk -based infant formula a Mik pouder a Condansed milk

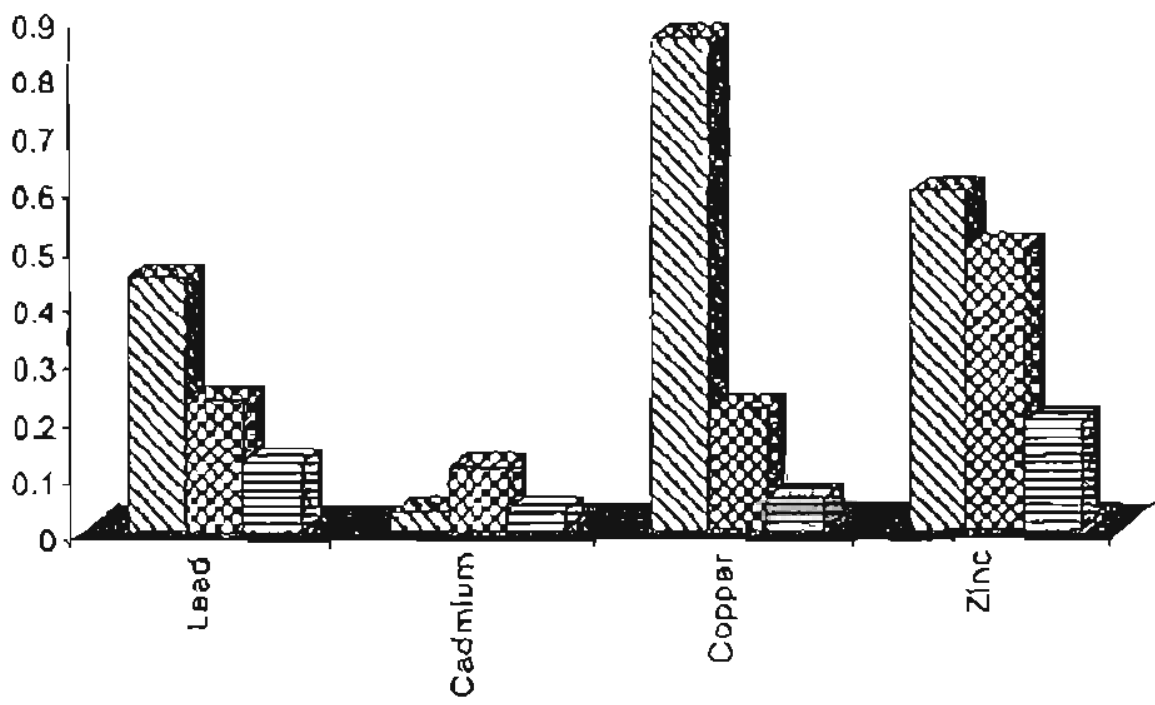

Fig. (1): Levels of Lead. Cadmlum. Copper and $Z$ lnc In examined canned dalry products (ppm).

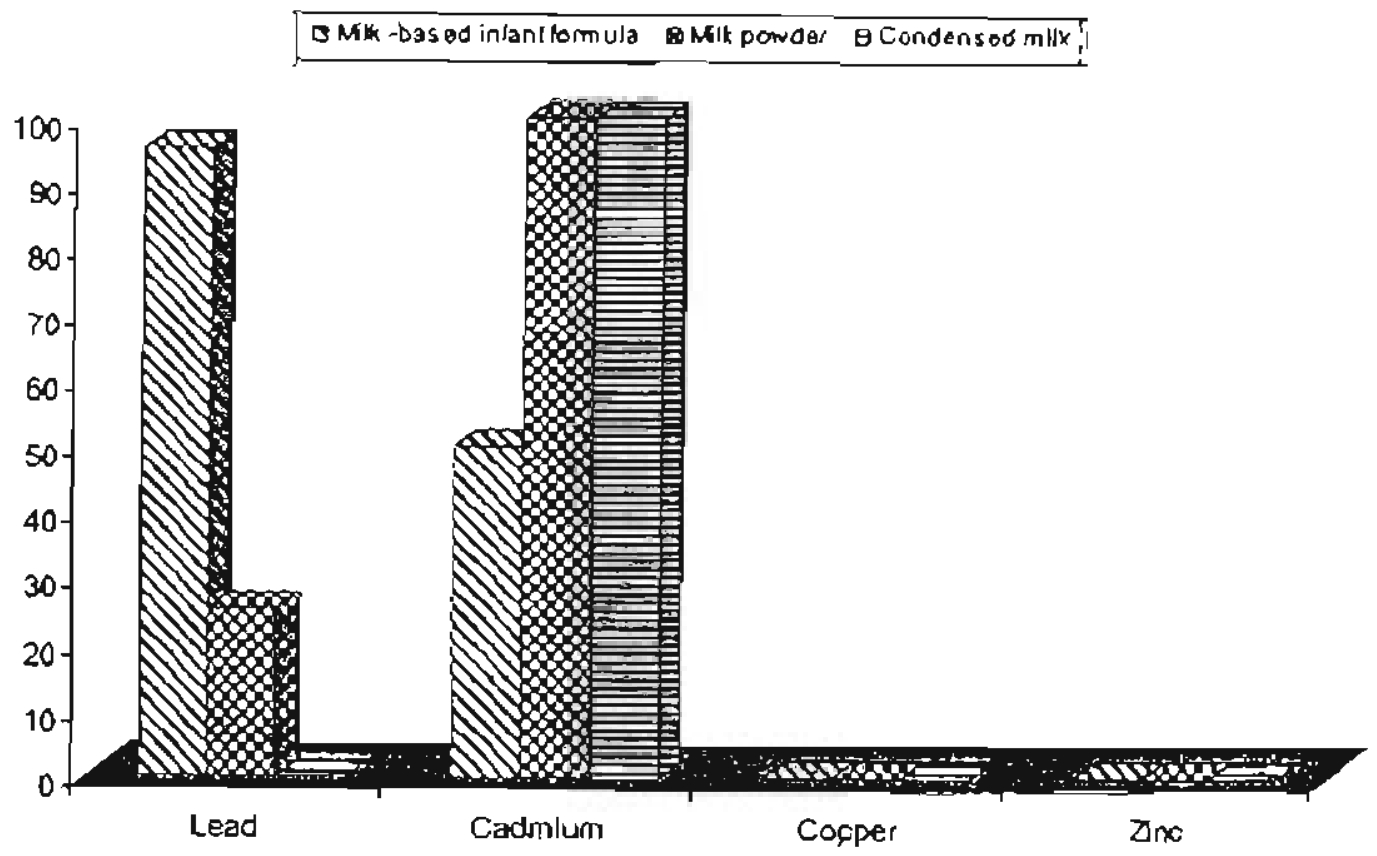

Fig. (2): Pcrcent of examined samples canned dalry products above MPL. 


\section{REFERENCES}

Agemaln, H.; Sturtevant, D. P. aad Austea, K. D. (1880) : Simullancous acld extracton of slx vace melals from flsh llssue by hot block -digesllon and detemininatlon by atomlc absorpuon spectrophotomelry.Analyst, 105-125.

Amer, H. I.; Amad, I. E. and Abd-elAal, S. F. (2006) : Prevelánce of lieavy melal residues In some baslc Infant dlet. B(h Scl. vel. Med. Zag. Conference (3 I Aug. 3Sepl.2006) Hurgha. da.

Aseoclation of officlal Analytical chemists (AOAC 1880) : Officlal Melhods of AJialysis. J. Assoc. Off.Anal. Chem. 63:485.13th Ed.. Arlinglon, VA.22201 USA.

Ayoub. Madeba. A A (2002): Trace elcmenis in some dalry produccs. AJex.J.Vel.Scl. 18 (1): $1 \cdot 15$.

Bawm. C. R aod Sbaunon, M. W. (1997) : The lead concentrauon of recollstiluled infant forniu. la. J.Toxicol.35 (4).

Blakl1, R.; Bladorz, J, and Libelt. B. (1992) : presence of some tracc clcmients in polisli food producls. Bromalologia. Chcmla loksykologicezna. 24(4):327.331.

Dlog. H. C.; Llu, H. J.: Sheu. Y. L. and Chang. T. C. (1993) : Survey of bela-laclam andubloucs and heavy metals in Iniant milk powder and human inllk. J.of food and drug Analysis! (3):265-271.

Egyptlan organlzation for standardization, EOS ( 1993 ) : Egypuan standards, maxmum level for heavy inetal contaminalli in ruods. E.S.2360. U.0.C. 546.19:815 Arab republlc of Egyis.

Ekluad. G. and Oskarsaan, R (1999): Exposure of cadmifum from Infant fornulas and weantng foods. Food Addle. Contant. 16(2):509:519.

El-Aglizy S. A (2005): Pollutlon of some babics food with heavy melals. Bull. High. linst.Pul. Health, 3514).

El-Malt. M. (2001) : Some heavy inclals and their licillh signifleance in milk and inllik products in Asslul govemorate. M.V.Sc. Milk Hyglene. Fact. Vet. Med. Asslul univ.

Payed. A. H. (2001): Study deteminaclon of some residues in milk alid inllk producls li) Alexandria govemorale. Ph.D. Thesls. Fac. Vet. Med. Alexandia univ.

Priberg. L.: Kdelletrom and Nardberg. G. F. (1886): Cadmlum in hand book on (he laxlcology of metals, vol.2,Frlberg. L., Nardberg.G.F. and Vouk.V.Q.leds.)Elsevier Amsterdam p.p. $130-184$. 
Funakoshl. T,; Ohta. O,: Shlmada, H. and Kojtma, 3. (1995) : Effects of dlthiocarbamates and cadmlum on the enzymauc acuviljes in liver, keldney. and blood or mice. Toxdcol. Lett. $78: 183-188$.

Gasarett, and Douls. J. (1996) : Toxlcology: the basic sclence of polsons. 5th Ed.Mcgraw-Hill compontes, Inc., New York

Golden, M. H. and Golden, B. E. (1981): Trace elements. potentlal Importance In human nutrUon with partlcular references lo zinc and vanadlum. Brtush Med.Bult.I (37):3)-36.

Gossel, T. A and Bricker, J. D. (1980) : Princlples of clinlcal toxicology (Textbook) 2nd Ed. Roven press. New York p.p. $153-192$.

Guldi, B.; Ronchi, S.; Mattel, P.; Trlpadi, A and Ori, E. (1996): The lead concentration in the converted and special formula mllks used In Irfant feeding. Med. Chlr., 18(3):275-277.

Magstad, H. V. and Hubbert,W, T. (1986) : Food quality control, foods of Animal ordgln.pp86-87. the lowa state univ.press. Aunes.

Hostgnek, Y. J.: Hinz. R. S.; Lorenz, C. R.: Price, M. and Guy, R. H. (1993) : Metals and the skin. Criucal reviews in loxicology. 23(2): 17 l-235.

Huang, Z.; Yang, G.; Hu, 8. and Yn, J. (2003) : Delermination of Lead. Cadmlum and Mercury in microwave digested foodsturts by RP-HPLC with an on-Jine entchment technlque. Anal ACl: 19\{201: 255-258.

Internatlonal Datry Federatlon I. D. F. (1979); Chemical Residues In milk and milk products. IDF. Bulleun No., 113.

Kairtgoharn, S. R.; Kgiser, M. L. and Flnderberger, E. J. (1982) : Food analysis for lead usIng furnace alomlc absorption and alvov platform.J.A.O.AC, 65:999-1004.

Khan, A.T.; Diffay, B. C.; Datis, B. C.; Forester, D. M.; Thompson, S. J. and Melke, H, W. (1995) : Heavy metals in livers and kldreys of goats in Alabama. Bull.Envion. Contam. Toxicol.; 55:568-575.

Klaaseen, C. D. (1985) : Heavy metals and heavy metal antagonists in the phannacological basts of therapeutics.7th Ed., A.J.Gilman, L.S., Goodman, T.w. and Murad,.p.p. 16051627. Macmillan,riewyork.

Klevag, L. M. (1975) : The relation of zinc and copper to blood liptd ieveis Amer.J.clin.NutraLion28:264-272

Kula, M. and Lasto, W. (1988) : Cans as a potentlal source of food contaminaton with lead and Zinc. Rocz. Panstw, Zakl, HIg. 37(1): 33-43. 
Madden, E. F. and Flower, B. A (2000): Mechanisin un nephroloxicity Irom melals contamlna. tion: A review. Drug cl)em. Loxical, 23(1):1-12

Mansour, M. H. (1989): Polluton of importcd dairy producls wiUl some lieavy melals and ucle publlc health signillicance. M.Sc., Nlex. Univ. 1999.

Narjagu, J. O. (1880): Zinc in Ue envilonmenl. Ecological cycling. Parl I New York. John Wiley. sons.

Nisblyama, S.; Nakamura, K. and Koalsb, Y. (1886) : Blood pressure and urinary sodium and polasslum excretion in cadinlum- Leated malc rats. Environ. Res :40:357-364.

Pope. A L. (1875) : Mlneral Inlerrelalionshlps in ovtne nutrition. J.A.m.vel.Med.Assoc.. J66:264.

Pownd, W. J. (1975) : Mineral Intenclatlonships in nutrition. Pracucal implicallons. Comel vel.. $65: 440$

Protaswickl. M. (1892) : Heavy melals content In the selected food. Jrd World Congress. food boine (nfection and intoxlcallon, 16-19 Junc, Berlin.

Rellyy. (1881): Melal conlaminatlon of hood. 2nd Ed.London. Elscuier.

Rlchard, F. P. and Rubla Shaplro. (1986) : Delcrminalion of tracc clements (n loods by hydro. chlorlc, nlerle acld leaching and hame alomlc absortion spectroscony. Joumal of AOAC. Int., $19(5): 868-870$.

Schraeder. H. A and Balassa. J. J. (1967) : Abnormal (race melals in man.Gemanlum ibld.20:211-224.

Shlbamoto, T. and Bjelaaes, L. P. (1993): Introduclion to loud toxicology Academlcpress. Inc. Marcourt brace and company. New York. Food scl.. technal. Sertes. I $26-132$.

Underwood. E. J. (1977) : Trace eleinent in human and anlmal nutriuon.4th Ed.Academic presslnc. London.

Hatanabe. T.; Zhang, Z. W.: Moon, C. S.; Shimbo, S.; Nakatsuka, H.: Matsuda-Logucbl, N.: Higashikwa. K. and Ikeda, M. (2000) : Cadmlum exposure of women In general popu. lauons in Japan during 1991-1997 comparcd with 1977-1981. Int. Arch. Occup. Envt. ron. Health: $73(1): 26-34$.

Wheaton, F. W. And Lawson, T. B. (1985): Processing of aqualic lood producl. Awlley incerscience publlcauon. Pp.231-232, Jhon Wiley and Sons New York, Toronto.

who (1973) : Envtronmertal Health Criterta.No.3.World Organization. WHO. Geneva. 160 pp. 
A. S. Alad and A. H. Fayed

WHO (1982) : Evalualion or Certain Food Additues and Contamlnants. WHO Technical Report Serles No.683. World Health Orgarlzation, Geneva. 


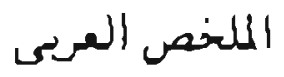

الخطورة الصحية للمعادن الثتِيلة فى بعض منتجات الألبان المعلبة المعن

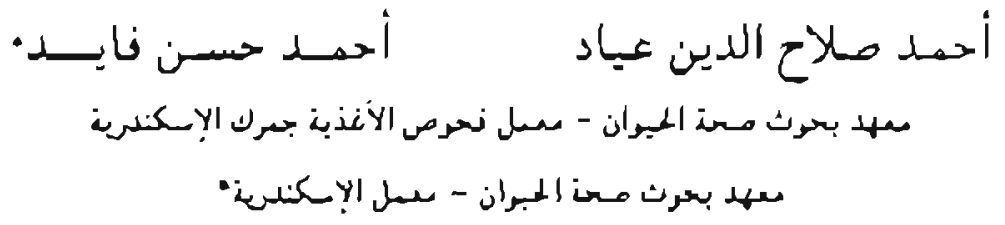

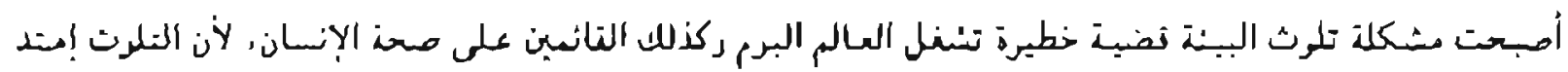

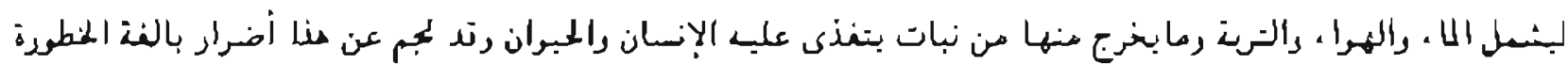

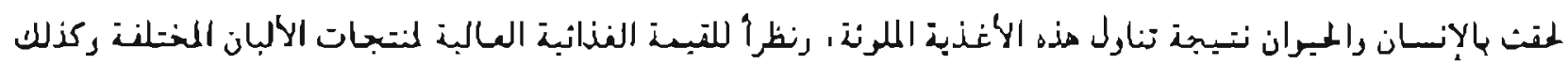

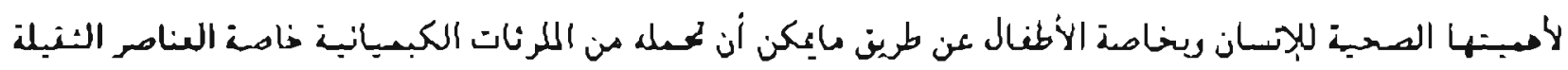

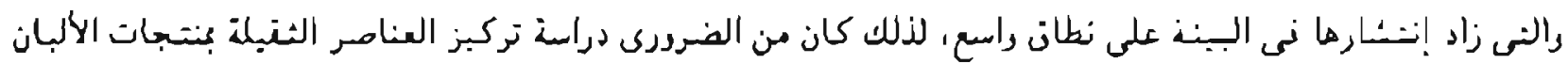

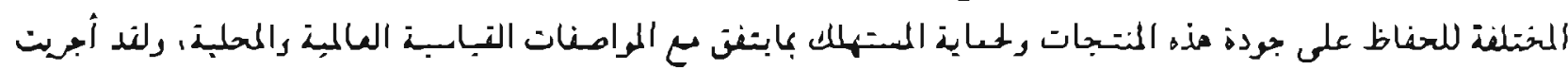

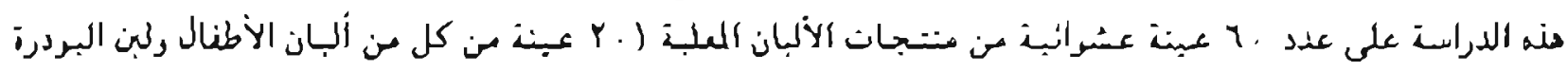

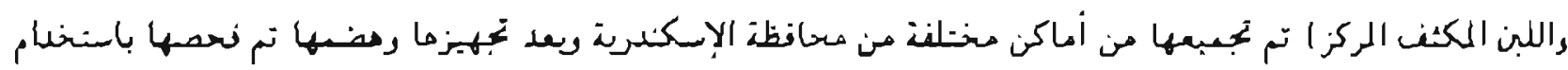

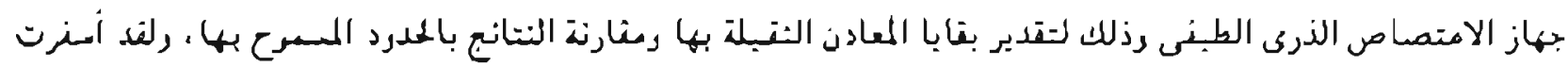

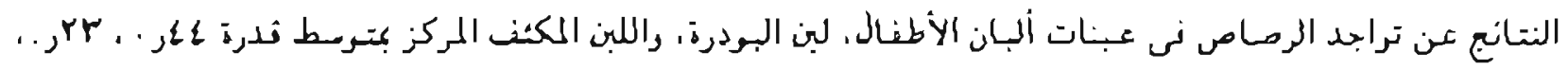

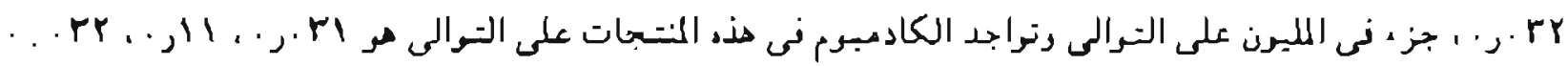

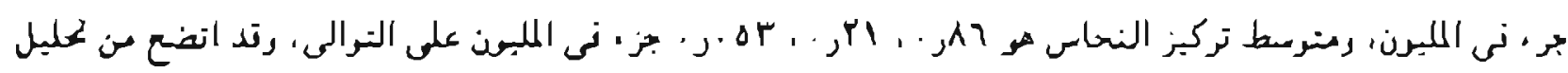

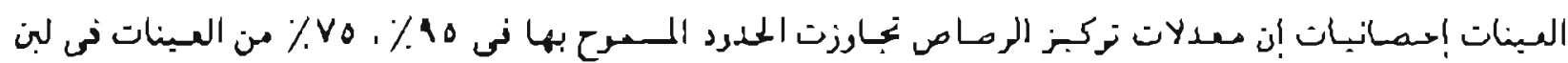

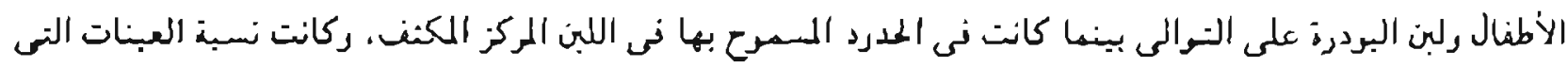

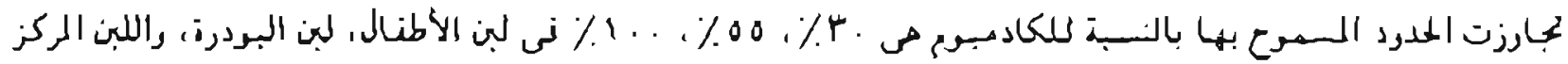

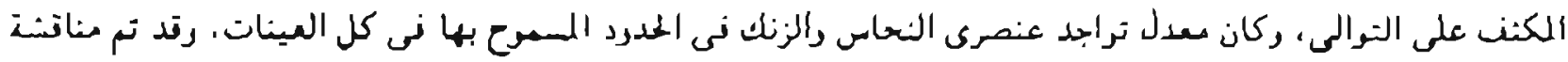

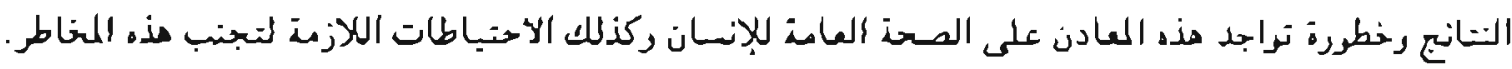

